\title{
Reliability and Validity of Consumers' Decision Making Investigation of Safe Street Food Purchasing, Pilot Study in Nakhon Si Thammarat, Thailand
}

\author{
J. Khongtong, M. S. Ab Karim, M. Othman, and J. B. Bolong
}

\begin{abstract}
Although street food has been the sources of unsafe food for consumption in the world including Thailand, it is interesting that many people are still choosing the food from here. The aim of this study is to investigate consumers' decision making regarding purchasing safe street food. There is very limited research in this area, therefore this study purposes to develop and test the quality of the instrument. The instrument was developed base on purchasing decision making model, and then tested the validity and reliability of data that collected from 150 pilot respondents by using SEM analysis. The results showed the drawn model was fit with the data. Moreover, the construct reliability $(\mathrm{CR}>0.7)$, convergent validity (AVE $>0.5)$ and discriminant validity (AVE $>r^{2}$ ) were acceptable. As a result, this instrument is capable to be applied in main study and test the research hypotheses. This pilot study can confirm that the instrument is workable and minimize the potential problem that probably occurs according to unclear instrument.
\end{abstract}

Index Terms-Consumer, decision making, food safety, reliability, street food, validity.

\section{INTRODUCTION}

The changing lifestyles and food consumption have influenced today's consumer's food purchasing behavior. Food preparation at home is replaced by eating out and becomes more frequent. As a result to the number of meals prepared outside the household has increased dramatically. Beside the need for eating, consumers also seek for convenience, so street food is the best answer for consumers in many countries [1].

Street food, according to FAO is defined as ready-to-eat-food that is prepared or sold by street vendors or hawkers in the public places. There are various types of food stalls such as push carts, roadside stands, balance basket, etc. The street food entrepreneur is operating in the major economic areas with heavy population density [2].

Nevertheless, food and beverage outside home is considered the source of food borne illness [3] and is one of the problems for people all over the world [4]. Poor hygienic practice of the vendors, comprising of improper cooking, inadequate food storage temperature, and food contamination can be all sources of microbial hazard to consumers that the

Manuscript received December 27, 2013; revised February 12, 2014.

J. Khongtong is with the Food Science and Technology, University Putra Malaysia, Malaysia (e-mail: j_khongtong@yahoo.com).

M. S. Ab Karim and M. Othman are with the Faculty of Food Science and Technology, University Putra Malaysia

J. B. Bolong is with the Faculty of Modern Languages and Communication, University Putra Malaysia. microbe is mostly found causing consumers food borne illness rather than other factors. Escherichia coli, coliforms and mesophilic bacteria have been discovered having the highest count in street food. However, the hazard can be prevented by paying attention to food preparation [5]. Food that is cooked properly is safe for consumption while the pre cooked food and the food is left for more than four hours is potential of risk. The mistake in hygiene of food preparation affects vast of consumers probably illness [6]. The percentage of patients who suffered from food borne disease in industrialized countries each year has been increased up to $30 \%$. The Canadian government has to allocate budget amount around $\$ 3.7$ billion dollars each year for 11 million cases of the illness [7].

The research group from FAO in 1995 reported that food safety is the most important aspect that should pay attention for street food in Asia [8]. Thailand has the one highest number of street vendors in Asia and many people depend on them for the meal because it is cheap and nutritious as well [9]. However, the food safety also is one of the main problems similarly like other countries [10] because the location of the food is prepared, sold or consumed is not appropriate and easily exposes to food contamination [11].

Nakhon Si Thammarat province, has the highest population in southern Thailand and [12] has past evidence that relates to unsafe street food. Many street vendors do not pass the food safety standard regulation mean while the demand of street food does not decrease respectively [13]. The decision making process of consumers when they are purchasing street food that is assumed risky becomes the central question in this study. Such information can investigate the factor that may enhance consumers concern in food safety and can contribute to the strategies that can protect consumers from unsafe food purchasing.

Decision Making Model of Blackwell known as of EMB model [14] is the basis model to develop street food purchasing model in this study. In addition, the study model is utilized to develop the research instrument to measure consumers' decision making under the apprehension of food safety.

There is a shortage of validated and reliable instrument to measure consumers' decision making in safe street food purchasing. Thus, this pilot study purposes to develop the validated and reliable instrument because there is no scholarly research work to date and attempt to design the instrument by involving all individual factors in decision after reviewing the literature thoroughly. 


\section{Methodology}

This pilot study aims to investigate the validity and reliability of consumers' decision making measurement instrument before applying it in the main study [15]. Moreover, the content of questionnaire was agreed by respondents in order to have clear terms and easy for respondents to understand.

TABLE I: RESPONDENTS PROFILE $(N=150)$

\begin{tabular}{|c|c|c|}
\hline $\begin{array}{c}\text { Demographic } \\
\text { Factor }\end{array}$ & Frequency & $\begin{array}{c}\text { Percentage } \\
(\%)\end{array}$ \\
\hline \multicolumn{3}{|l|}{ 1. Age } \\
\hline $20-30$ & 123 & 82 \\
\hline $31-40$ & 21 & 14 \\
\hline $41-50$ & 6 & 4 \\
\hline Total & 150 & 100 \\
\hline \multicolumn{3}{|l|}{ 2. Gender } \\
\hline Male & 41 & 27.3 \\
\hline Female & 109 & 72.7 \\
\hline Total & 150 & 100 \\
\hline \multicolumn{3}{|l|}{ 3. Status } \\
\hline Single & 128 & 85.3 \\
\hline Married & 21 & 14 \\
\hline Widowed & 1 & 0.7 \\
\hline Total & 150 & 100 \\
\hline \multicolumn{3}{|l|}{$\begin{array}{l}\text { 4. Household } \\
\text { member }\end{array}$} \\
\hline 1 person & 12 & 8 \\
\hline 2 persons & 13 & 8.7 \\
\hline 3 persons & 27 & 18 \\
\hline 4 persons & 43 & 28.7 \\
\hline 5 persons & 26 & 17.3 \\
\hline 6 persons & 20 & 13.3 \\
\hline$>7$ persons & 9 & 6 \\
\hline Total & 150 & 100 \\
\hline \multicolumn{3}{|l|}{$\begin{array}{l}\text { 5. Highest } \\
\text { education }\end{array}$} \\
\hline Secondary & 58 & 38.7 \\
\hline Diploma & 46 & 30.7 \\
\hline Bachelor & 39 & 26 \\
\hline$>$ Bachelor & 7 & 4.7 \\
\hline Total & 150 & 100 \\
\hline \multicolumn{3}{|l|}{ 6. Occupation } \\
\hline Student & 87 & 58 \\
\hline Self employment & 11 & 7.3 \\
\hline Private & 5 & 3.3 \\
\hline State enterprise & 2 & 1.3 \\
\hline Government & 39 & 26 \\
\hline Housewife & 5 & 3.3 \\
\hline Others & 1 & 0.7 \\
\hline Total & 150 & 100 \\
\hline \multicolumn{3}{|l|}{ 7. Income (Bath) } \\
\hline$<5,000$ & 43 & 28.7 \\
\hline $5,000-10,000$ & 40 & 26.7 \\
\hline $10,001-15,000$ & 45 & 30 \\
\hline $15,001-20,000$ & 12 & 8 \\
\hline $20,001-30,000$ & 4 & 2.7 \\
\hline $30,001-40,000$ & 3 & 2 \\
\hline$>40,000$ & 3 & 2 \\
\hline Total & 150 & 100 \\
\hline
\end{tabular}

$1 \mathrm{US} \$ \approx 30$ Bath

\section{A. Instrument Development}

The variables in questionnaire were determined base on the conceptual of consumers' purchasing decision making in EMB model [14]. The items for each variable were drawn from the modification of previous literature; consumers' attitude [15], [16], consumers' motivation [17], consumers' lifestyle [18], consumers' resources , consumers' need [19], [20], consumers' pre-purchase evaluation [21], [22], consumers' purchasing [21], [22], consumers' attitude toward food safety certificate [23] together with preliminary study: observation and in-depth interview, by focusing only on food safety. The respondents were asked to address their opinion or behavior in 7 point linkert scale with 1 represented strongly disagree or never involved in that particular behavior and 7 represented strongly agree or absolutely involved in that particular behavior.

\section{B. Sample and Data Collection}

Pilot study was done at one street food center located in front of a university in NST province. Consumers who are aged between 20 - 60 years old, were a resident in NST province at least 1 year and had patronage street food no longer than 6 months were asked to participate in the study by using convenience sampling data collection technique which was the common technique in psychological research [24]. The pilot study of 150 participants and their demographic profiles are demonstrated in Table I. According to Simon [2], $10-20 \%$ of total respondents in main study is reasonable to be a number of respondents in the pilot study.

\section{Statistical Analysis}

The returned questionnaires were tabulated using SPSS software version 20 and demographic profiles of the respondents were analyzed using descriptive analysis. Structural Equation Model analysis using AMOS software version 20 was applied to test confirmatory factor analysis (CFA) of measurement model that will reveal the validity and reliability of research the instrument [4]. The validated and reliable instrument in pilot study illustrates that the instrument will probably have no problem when employed to main study [13].

\section{RESUlt AND DisCUSSION}

\section{A. Model Fit}

Analyzing 2 levels of measurement model was done with confirmatory factor analysis and the model approached good fit according to critical fit index by the yield of: relative Chi-Sq $(\mathrm{CMIN} / \mathrm{DF})=1.33(<5.0)$ [25], [26] comparative fit index $(\mathrm{CFI})=0.94(>0.9)$ [27], [28], Incremental Fit Index $(\mathrm{IFI})=0.94(>0.9)$ [26], Tucker- Lewis index $(\mathrm{TLI})=0.93(>$ 0.9) [29], and root mean squared error of approximation $($ RMSEA $)=0.05(<0.08)$ [30]. Thus, this measurement model based on EMB model was fit satisfactorily with the data and could be used for street food purchasing decision explanation.

\section{B. Construct Reliability and Convergent Validity}

The measurement model with 33 items with all factors loading exceed 0.5 which are significant at $p<0.001$, so all the items achieved the recommended value and they are valid [23] to be parameters in construct reliability (CR) and average variance extracted (AVE) calculation. The values of those both parameters are demonstrated in Table II. The construct reliability (CR) is ranging from 0.74 to 0.89 that 
shows good internal consistency $(0.75$ - 0.90) [31] other than consumers' purchasing factor which is 0.74 however the reliability of consumers' purchasing construct is acceptable (CR > 0.7) [32]. AVE value in the last column of Table II presents convergent validity of construct. The construct are considered valid when the AVE of each construct higher than 0.5 [32]. In Table II, all constructs have AVE is ranging from 0.51 to 0.66 that are valid except consumers' purchasing $(\mathrm{AVE}=0.42)$. Taking the low AVE of this construct into consideration, consumers' purchasing variable probably be decided to be dropped from structural model if in main study the variable has still been exhibited value under the recommended level [1].

\section{Discriminant Validity}

Discriminant validity was determined by comparing $\mathrm{r}^{2}$ of each pair of variables as the data shown in Table III against their AVE (Table II) of those two variables, if the AVE $>r^{2}$, the discriminant validity supported. All variables in this measurement model meet the criteria of discriminant validity. Thus, this instrument confirms discriminant validity and the individual variable will not measure the same thing [24], [32].

Nonetheless, overall validated and reliable of instrument in pilot test should be taken into consideration in terms of the accuracy because of limited number of participants [33].

TABLE II: RESUlt OF CONFIRMATORY FACTOR ANALYSIS OF CONSUMERS’ DECISION MAKING IN SAFE STREET FoOd PURCHASING ( $N=150)$

\begin{tabular}{|c|c|c|c|c|c|}
\hline $\begin{array}{l}\text { Factor } \\
\text { Codes }\end{array}$ & Items & $\begin{array}{c}\text { Factor } \\
\text { Loading }\end{array}$ & $\begin{array}{c}\text { Mean } \\
(\mathrm{SD})\end{array}$ & $\mathrm{CR}$ & AVE \\
\hline $\begin{array}{l}\text { Consumers' } \\
\text { Attitude } \\
\text { (CATT) }\end{array}$ & $\begin{array}{l}\text { Improper food storage can be a health hazard. } \\
\text { Meat should be prepared well done. } \\
\text { Negative effects of food may affect my health. } \\
\text { We should enjoy the food, but still aware about the food safety. }\end{array}$ & $\begin{array}{l}0.55 \\
0.65 \\
0.74 \\
0.87\end{array}$ & $\begin{array}{l}5.98(1.28) \\
6.39(1.01) \\
6.24(1.11) \\
6.22(.98) \\
\end{array}$ & 0.80 & 0.51 \\
\hline $\begin{array}{l}\text { Consumers' } \\
\text { Motivation } \\
(\mathrm{CMOT})\end{array}$ & $\begin{array}{l}\text { I pay attention on food safety because... } \\
\text { It can help me prevent food poisoning. } \\
\text { It can force the vendors to improve their food safety practices. } \\
\text { I am concerned with my health. } \\
\text { It relates to my lifestyle. }\end{array}$ & $\begin{array}{l}0.66 \\
0.67 \\
0.71 \\
0.84\end{array}$ & $\begin{array}{l}6.31(.85) \\
6.05(1.02) \\
6.21(1.03) \\
5.95(1.05) \\
\end{array}$ & 0.81 & 0.52 \\
\hline $\begin{array}{l}\text { Consumers' } \\
\text { Lifestyle } \\
\text { (CLIF) }\end{array}$ & $\begin{array}{l}\text { I buy street foods because... } \\
\text { It is not expensive. } \\
\text { It will reduce the amount of food preparation and washing up. } \\
\text { It allows me to have more time to relax. } \\
\text { I really enjoy buying street food. }\end{array}$ & $\begin{array}{l}0.81 \\
0.81 \\
0.88 \\
0.74\end{array}$ & $\begin{array}{l}4.61(1.65) \\
4.50(1.66) \\
4.37(1.73) \\
4.00(1.57) \\
\end{array}$ & 0.89 & 0.66 \\
\hline $\begin{array}{l}\text { Consumers' } \\
\text { Resources } \\
\text { (CRES) }\end{array}$ & $\begin{array}{l}\text { Price is important for me when selecting } \\
\text { a place. } \\
\text { Street food is suitable for low income. } \\
\text { Distance is important. } \\
\text { Eating street food can save time for me. }\end{array}$ & $\begin{array}{l}0.71 \\
0.65 \\
0.83 \\
0.65\end{array}$ & $\begin{array}{l}4.73(1.57) \\
4.59(1.70) \\
4.71(1.42) \\
4.75(1.41)\end{array}$ & 0.80 & 0.51 \\
\hline $\begin{array}{l}\text { Consumers' } \\
\text { Need } \\
\text { (CNEE) }\end{array}$ & $\begin{array}{l}\text { The stall should provide clean utensils. } \\
\text { The vendor should demonstrate personal hygiene. } \\
\text { The food should be cooked properly. } \\
\text { No pest or domestic animal around the stall. }\end{array}$ & $\begin{array}{l}0.83 \\
0.88 \\
0.70 \\
0.76\end{array}$ & $\begin{array}{l}6.45(.91) \\
6.38(1.01) \\
6.46(.82) \\
6.49(.83) \\
\end{array}$ & 0.87 & 0.63 \\
\hline $\begin{array}{l}\text { Consumers' } \\
\text { Pre Purchase } \\
\text { Evaluation } \\
\text { (CPRE) }\end{array}$ & $\begin{array}{l}\text { I check the vendors' appearance. } \\
\text { I observe the vendors' behavior. } \\
\text { I check if there's an undesirable smell. } \\
\text { I concern the presentation of food. }\end{array}$ & $\begin{array}{l}0.78 \\
0.89 \\
0.76 \\
0.57\end{array}$ & $\begin{array}{l}5.13(1.36) \\
5.25(1.26) \\
5.37(1.32) \\
5.87(1.13) \\
\end{array}$ & 0.84 & 0.58 \\
\hline $\begin{array}{l}\text { Consumers' } \\
\text { Purchasing } \\
\text { (CPUR) }\end{array}$ & $\begin{array}{l}\text { I will choose the stall with good food aroma. } \\
\text { I will not buy food from other stalls. } \\
\text { I will not choose too crowded stalls. } \\
\text { After receiving good information about the stall, I will go to that } \\
\text { particular stall. }\end{array}$ & $\begin{array}{l}0.59 \\
0.66 \\
0.67 \\
0.67\end{array}$ & $\begin{array}{l}5.13(1.24) \\
4.22(1.62) \\
4.46(1.41) \\
4.53(1.25)\end{array}$ & 0.74 & 0.42 \\
\hline $\begin{array}{l}\text { Consumers' } \\
\text { Attitude } \\
\text { Toward Food } \\
\text { Safety } \\
\text { Certificate } \\
\text { (CFSC) }\end{array}$ & $\begin{array}{l}\text { I believe all certified stalls carry out food safety practices. } \\
\text { I trust certified stalls use good food preparation techniques. } \\
\text { I do not trust when it is not certified. } \\
\text { The certificate is an assurance of food safety. } \\
\text { The presence of the certification attracts me. }\end{array}$ & $\begin{array}{l}0.78 \\
0.81 \\
0.51 \\
0.78 \\
0.67\end{array}$ & $\begin{array}{l}5.26(1.29) \\
5.09(1.30) \\
4.95(1.36) \\
5.40(1.35) \\
5.20(1.34)\end{array}$ & 0.84 & 0.52 \\
\hline
\end{tabular}

TABLE III: SQUARE OF CORRELATION COEFFICIENT BETWEEN TWO VARIABLES

\begin{tabular}{|c|c|c|c|c|c|c|c|c|}
\hline \multicolumn{9}{|c|}{ Square of Correlation Coefficient $\left(r^{2}\right)$} \\
\hline Variable Codes & 1 & 2 & 3 & 4 & 5 & 6 & 7 & 8 \\
\hline 1. CATT & - & & & & & & & \\
\hline 2. CMOT & 0.504 & - & & & & & & \\
\hline 3.CLIF & 0.014 & 0 & - & & & & & \\
\hline 4.CRES & 0.003 & 0.001 & 0.168 & - & & & & \\
\hline 5.CNEE & 0.130 & 0.063 & 0.032 & 0 & - & & & \\
\hline 6.CPRE & 0.048 & 0.023 & 0 & 0.001 & 0.044 & - & & \\
\hline 7. CPUR & 0.020 & 0.044 & 0.109 & 0.058 & 0.014 & 0.109 & - & \\
\hline 8.CFSC & 0.005 & 0.003 & 0.084 & 0.006 & 0.001 & 0.005 & 0.116 & - \\
\hline
\end{tabular}




\section{CONCLUSION}

This pilot study focused on testing the validity and reliability of the instrument to avoid inappropriate questions in the main study. The measurement model was confirmed fit with data, and all factors met the criteria of reliability and validity. Even though one variable: consumers' purchasing, had AVE value a little bit less than the recommended value, the other items met the criteria, so this instrument was satisfactory to be applied in further study. This study will benefit future researchers in order to evaluate the level of validity and reliability of this instrument for measuring consumers concern regarding safe street food purchasing. Nevertheless, the nature of street food consumption varies based on the location or different demographic. Data collection from a diverse group of consumers will have a wider perspective.

\section{LIMITATION}

This study aimed to examine the reliability and validity of instrument, so the number of respondents in this study was only for trial in pilot scale and too specific for one group. The information in this study cannot be representative for the street food purchasing behavior of consumers in whole province however the confirmation about validated and reliability of decision making instrument from this pilot study can further be applied in the main study. The success in validity and reliability of instrument test in pilot study cannot warrantee it will be completely in the full scale study.

\section{REFERENCES}

[1] J. Choi, A. Lee, and C. Ok, "The effects of consumers' perceived risk and benefit on attitude and behavioral intention: A study of street food," Journal of Travel and Tourism Marketing, vol. 30, pp. 222-237, 2013.

[2] Food Agriculture Organization, Street foods, Report of an FAO expert consultation, (meeting No. 46). Jogjakarta, Indonesia: FAO Food Nutr, 1990.

[3] A. J. Knoght, M. R. Worosz, and E. C. D. Todd, "Serving food safety: Consumer perceptions of food safety at restaurants," International Journal of Contemporary Hospitality Management, vol. 19, no. 6, pp. 476-484, 2007.

[4] Dietitians of Canada, "Microbial food safety and reported consumer practices," Current Issues Newsletter, December, pp. 1-6, 2007.

[5] Food Agriculture Organization. (2008). [Online]. Available: http://www.fao.org/ fishery/ topic. 12328

[6] J. Hertzman, and D. Barrash, "An assessment of food safety knowledge and practices of catering employees," British Food Journal, vol. 109, no. 7, pp. 562-576, 2007.

[7] S. E. Majowicz, V. L. Edge, A. F. McNab, W. B. K. A. Dore, P. N. Sockett, and J. B. Wilson, "Estimating the under-reporting rate for infectious gastrointestinal illness in Ontario," Canadian Journal of Public Health, vol. 96, no. 3, pp. 178-181, 2005.

[8] Food Agriculture Organization, Street foods. Report of an FAO Technical Meeting on Street Foods, Calcutta, India, 6-9 November 1995, (meeting No. 63). Calcutta, India, 1997.

[9] S. K. Bhowmik, "Street vendors in Asia: A review," Economic and Political Weekly, vol. 40, no. 22-23, pp. 2256-2264, 2005.

[10] N. Nirathron, Fighting Poverty from the Street: A Survey of Street Food Vendors in Bangkok, Bangkok, Thailand: International Labour Organization, 2006.

[11] C. Muyanja, L. Nayiga, N. Brenda, and G. Nasinyama, "Practices, knowledge and risk factors of street food vendors in Uganda," Food Control, vol. 22, pp. 1551-1558, 2011.

[12] Ministry of Interior. (2012). [Online]. Available: http://www.dopa.go. th
[13] Ministry of Public Health. (2012). [Online]. Available: http://foodsan.anamai.moph.go.th

[14] R. D. Blackwell, P. W. Miniard, and J. F. Engel, Consumer Behavior, 10th ed. Singapore: Thomson South Westhern, 2006.

[15] I. Angelillo, N. M. A. Viggiani, L. Rizzo, and A. Bianco, "Food handlers and food borne diseases," Journal of Food Protection, vol. 63, pp. 381-385, 2000 .

[16] A. Ucar, Y. Ozdogan, and A. O. Ozcelik, "Consumer attitude toward food consumption and purchase in turkey," Ecology of Food and Nutrition, vol. 51, pp. 492-504, 2012

[17] M. F. Chen, "The joint moderating effect of health consciousness and healthy lifestyle on consumers' willingness to use functional foods in Taiwan," Appetite, vol. 57, pp. 253-262, 2011.

[18] M. C. Buckley, C. Cowan, M. Mccarthy, and C. Sullivan, "The convenience consumer and food-related lifestyles in Great Britain," Journal of Food Products Marketing, vol. 11, no. 3, pp. 3-25, 2005.

[19] U. Buchholz, G. Run, J. L. Kool, J. Fielding, and L. Mascola, "A risk-based restaurant inspection system in Los Angeles County," Journal of Food Protection, vol. 65, no. 2, pp. 367-372, 2002.

[20] U. Z. A. U. Fatimah, H. C. Boo, M. Smbasivan, and R. Salleh, "Food service hygiene factors the consumer perspective," International Journal of Hospitality Management, vol. 30, pp. 38-45, 2011.

[21] M. S. Danelon and E. Salay, "Development of a scale to measure consumer perception of the risks involved in consuming raw vegetable salad in full-service restaurants," Appetite, vol. 59, no. 3, pp. 713-722, 2012.

[22] E. C. Redmond and C. J. Griffith, "Consumer food handling in the home: A review of food safety studies," Journal of Food Protection, vol. 66, no. 1, 130-161, 2013.

[23] P. L. Uggioni and E. Salay, "Reliability and validity of a scale to measure consumer attitudes regarding the private food safety certification of restaurants," Appetite, vol. 58, pp. 470-477, 2012.

[24] B. C. Y. Lee, "Consumer attitude toward virtual stores and its correlates," Journal of Retailing and Consumer Services, vol. 14, pp. 182-191, 2007.

[25] N. J. Blunch, "Introduction to structural equation modelling using SPSS and AMOS," London, UK: SAGE, 2008.

[26] H. W. Marsh and D. Hocevar, "Application of confirmatory factor analysis to the study of self-concept: First- and higher order factor models and their invariance across groups," Psychological Bulletin, vol. 97, no. 3, pp. 562-582, 1985.

[27] P. M. Bentler, "Comparative fit indexes in structural models," Psychological Bulletin, vol. 107, no. 2, pp. 238-246, 1990.

[28] L. Hatcher, A step-by-step approach to using the SAS system for factor analysis and structural equation modeling, Cary, NC: The SAS Institute, 1994, pp. 325-339.

[29] L. R. Tucker and C. Lewis, "A reliability coefficient for maximum likelihood factor analysis," Psychometrika, vol. 38, pp. 1-10, 1973.

[30] B. M. Byrne, Structural Equation Modeling with AMOS, New York, USA: Taylor and Francis, 2010.

[31] J. C. Nunnally and I. H. Bernstein, Psychometric Theory, New York, USA: McGraw-Hill, 1994.

[32] Y. A. Aziz and N. V. Chok, "The role of Halal awareness, Halal certification, and marketing components in determining Halal purchase intention among non-Muslims in Malaysia: A structural equation modeling approach," Journal of International Food and Agribusiness Marketing, vol. 25, pp. 1-23, 2013.

[33] E. R. V. Teijlingen and V. Hundley, The Importance of Pilot Studies, Guildford, UK: Department of Sociology University of Surrey, 2011.

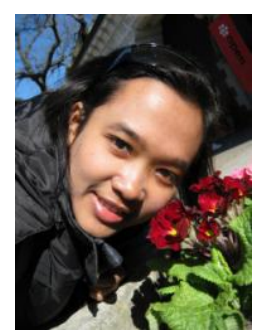

J. Khongtong was born in Nakorn Si Thammarat, Thailand, on April 15, 1982. He has received Ph.D candidate in food service and management, Faculty of Food Science and Technology, University Putra Malaysia, Malaysia, 2011. His first degree is B.Sc. (Agro-Industry), Prince of Songkhla University, SongKhla, Thailand, 2002; pursue with M.S. (Food Technology), The University of Chulalongkorn, Bangkok, Thailand, 2007. He worked as a lecturer in food Science and Technology Program, Faculty of Science and Technology, Nakhon Si Thammarat Rajabhat University, Nakhon Si Thammarat, Thailand, 2007- 2013, and in Food and Nutrition Program, Faculty of Science and Technology, Nakhon Si Thammarat Rajabhat University, Nakhon Si Thammarat, Thailand, 2013 


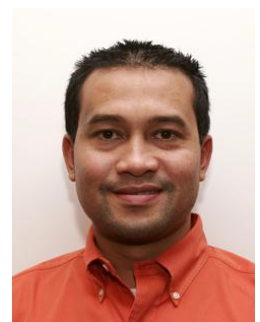

M. S. Ab Karim is a member of qualitative research association of Malaysia. He was born in Malacca, Malaysia in 1970s. His first degree is B.Sc. degree in hotel and restaurant management, New York University, New York, 1994. Also, He is pursuing with MBA in University of Technology MARA, Shah Alam, Selangor. He was awarded doctor of philosophy degree in human environmental sciences with a specialization in Hospitality Tourism Adminstration, School of Hotel \& Restaurant Administration, College of Human Environmental Sciences, Oklahoma State University, Stillwater Oklahoma. Summer 2006 (Dissertation Topic: Culinary tourism as a destination attraction: An empirical examination of the destination's food image and information sources). Previously, He has been working as special assistant to the Vice President Malaysia at Malaysia Tourism
Promotion Board, New York, 1993-1997 and as Guest Service Manager at Sheraton New York Hotel \& Towers, Manhattan, New York, 1994-1997. Currently, as associate professor (Culinary Arts \& Food Culture), Department of Foodservice Management, Faculty of Food Science and Technology, University Putra, Malaysia. His publication of several books include Sajian Eksotik Warisan Bugis (Exotic Bugis Heritage Food Kuala Lumpur, Berita Publishing, Ab Karim, M.S. and Ismail,N , 2012 and Malaysia Food Culture: In Food Cultures of the World Encylopedia. California, Greenwood Publication, Ab Karim, S. and Abdul Ghani, C.A., 2011 and his interest is in doing several research papers regarding to food culture and culinary tourism. Dr. Ab Karim was invited as panel expert for international program by National Institute of Food Science and Technology at University of Agriculture, Faisalabad, Pakistan, reviwers for manuscripts and journal of agribusiness marekting and also actively involved as professional juries through invited media such as television program on Materchef Malaysia season 1 and 2. 